\title{
Evidence for an inhibitory role of bone morphogenetic protein(s) in the follicular-luteal transition in cattle
}

\author{
Amjad R Kayani, Claire Glister and Philip G Knight \\ School of Biological Sciences, University of Reading, Whiteknights, Reading RG6 6AJ, UK \\ Correspondence should be addressed to P G Knight; Email: p.g.knight@reading.ac.uk
}

\begin{abstract}
Bone morphogenetic proteins (BMPs) and their receptors are expressed in ovarian theca cells (TC) and granulosa cells (GC) and BMPs have been implicated in the regulation of several aspects of follicle development including thecal androgen production and granulosal oestrogen production. Their potential involvement in luteal function has received less attention. In this study, we first compared relative abundance of mRNA transcripts for BMPs, activin- $\beta A$ and BMP/activin receptors in bovine corpus luteum $(\mathrm{CL})$ and follicular theca and granulosa layers before undertaking functional in vitro experiments to test the effect of selected ligands (BMP6 and activin A) on luteinizing bovine TC and GC. Relative to $\beta$-actin transcript abundance, $C L$ tissue contained more BMP4 and -6 mRNA than granulosa, more BMP2 mRNA than theca but much less activin- $\beta A$ mRNA than both granulosa and theca. Transcripts for all seven BMP/activin receptors were readily detected in each tissue and two transcripts (BMPRII, ActRIIA) were more abundant in CL than either theca or granulosa, consistent with tissue responsiveness. In vitro luteinization of TC and GC from antral follicles (4-6 mm) was achieved by culturing with $5 \%$ serum for 6 days. Treatment with BMP6 (0, 2, 10 , and $50 \mathrm{ng} / \mathrm{ml})$ and activin $A(0,2,10$ and $50 \mathrm{ng} / \mathrm{ml})$ under these conditions dose-dependently suppressed forskolin-induced progesterone (P4) secretion from both cell types without affecting cell number. BMP6 reduced forskolin-stimulated upregulation of STAR mRNA and raised 'basal' CYP17A1 mRNA level in theca-lutein cells without affecting expression of CYP11A1 or hydroxy- $\Delta-5$-steroid dehydrogenase, $3 \beta$ - and steroid $\Delta$-isomerase 1 (HSD3B1). In granulosa-lutein cells, STAR transcript abundance was not affected by BMP6, whereas forskolin-induced expression of CYP11A1, HSD3B1, CYP19A1 and oxytocin transcripts was reduced. In both cell types, follistatin attenuated the suppressive effect of activin A and BMP6 on forskolin-induced P4 secretion but had no effect alone. Granulosa-lutein cells secreted low levels of endogenous activin $A(\sim 1 \mathrm{ng} / \mathrm{ml}) ; B M P 6$ reduced this, while raising follistatin secretion thus decreasing activin A:follistatin ratio. Collectively, these findings support inhibitory roles for BMP/activin signalling in luteinization and steroidogenesis in both TC and GC.

Reproduction (2009) 137 67-78
\end{abstract}

\section{Introduction}

Little is known about the early stages of luteinization, the process by which both granulosa cells (GC) and theca cells (TC) of the post-ovulatory follicle develop into the corpus luteum (CL). Also, the local regulation of the development and regression of the $\mathrm{CL}$, marked by the rise and decline of progesterone (P4) levels, has yet to be fully delineated. Luteinization leads to an oestrogenic to progestagenic shift in follicular steroidogenesis, through upregulation of various components of the steroidogenic pathway in both theca-lutein and granulosa-lutein cells of the CL. These include STAR, hydroxy- $\Delta-5$-steroid dehydrogenase, $3 \beta$ - and steroid $\Delta$-isomerase 1 (HSD3B1) and CYP11A1 (Ireland et al. 1980, Rodgers et al. 1987, Couet et al. 1990, Stocco 2000) Conversely, expression of cytochrome P450, family 17 , subfamily A, polypeptide 1 (CYP17A1), required for androgen synthesis by TC, and P450 aromatase (CYP19A1) required for conversion of androgens to oestrogens by GC, decrease sharply after the preovulatory LH surge
(Rodgers et al. 1987). Other changes in sheep and cattle include decreased secretion of inhibin (Martin et al. 1991) and increased secretion of oxytocin (Schams 1987, Luck et al. 1990) by GC.

It is well established that intraovarian factors belonging to the transforming growth factor $\beta$ (TGF $\beta$ ) superfamily, including activins, inhibins and bone morphogenetic proteins (BMPs), are synthesized by follicular GC and TC cells and these proteins have been assigned roles as local autocrine/paracrine regulators of follicle growth and development (Shimasaki et al. 2004, Juengel \& McNatty 2005, Knight \& Glister 2006). However, relatively little is known regarding the expression and role of BMPs in luteinization and $\mathrm{CL}$ function.

The biological effects of BMPs are mediated by specific cell-surface receptors, which exist as two subtypes: type I and type II (Massague 1996), both with intrinsic serine/threonine kinase activity. BMP signalling requires binding to and formation of heteromeric complexes with the type I and type II receptors on the 
cell surface (Massague \& Chen 2000, Miyazono et al. 2000, Miyazawa et al. 2002). Once the BMPR-ligand complex is formed, the type II receptor phosphorylates and activates the type I receptor, which in turn activates transcriptional regulators called Smads. BMPs can bind to one of three type II receptors (BMPRII, ActRIIA or ActRIIB) and one of three type I receptor (BMPRIA, BMPRIB or ActRIA). BMP4 and -7 are expressed in rat (Shimasaki et al. 1999, Lee et al. 2001) and bovine (Glister et al. 2004) TC while BMP6 expression has been reported in mouse (Elvin et al. 2000) and bovine (Glister et al. 2004) oocytes. Ovine GC have been reported to express BMP2 (Souza et al. 2002) while BMP6 immunoreactivity was detected in bovine GC (Glister et al. 2004). Treatment of non-luteinized bovine GC with BMP4, -6 and -7 enhanced basal and IGF-induced secretion of oestradiol, inhibin $A$, activin $A$ and follistatin but inhibited basal and IGF-induced secretion of (Glister et al. 2004). Treatment of non-luteinized bovine TC with the same three ligands potently suppresses basal and LH-induced androgen secretion and CYP17A1 mRNA and protein expression (Glister et al. 2005).

Such evidence from functional studies on nonluteinized GC and TC suggest a role of these locally derived BMPs in follicular steroidogenesis. With this in mind, the aim of the present study was to extend these observations to the follicular-luteal transition: 1) by using real-time quantitative PCR to compare ex vivo expression of mRNA transcripts encoding selected BMP ligands and receptors in bovine $\mathrm{CL}$, granulosa and theca tissue and 2) by examining the effect of selected ligands (BMP6, activin A) and an associated-binding protein (follistatin) on steroid production and steroidogenic gene expression by bovine GC and TC undergoing seruminduced luteinization in vitro.

\section{Results \\ Comparison of $m R N A$ transcript abundance in ex vivo samples of $C L$, theca and granulosa tissue}

mRNA transcripts for a range of BMP-related ligands, receptors and steroidogenic pathway components were readily detectable in freshly harvested samples of $C L$ and follicular granulosa and theca tissue (Table 1). The pattern of expression of steroidogenic pathway components in the three tissues was as expected: relative expression of STAR, CYP11A1 and HSD3B1 was substantially greater in $\mathrm{CL}$ tissue than in either GC or TC. In addition, expression of CYP19A1 was much greater in GC than either CL or TC while expression of CYP17A1 was much greater in TC than either $\mathrm{CL}$ or GC. The relative amounts of BMP2, -4 and -6 transcript in $\mathrm{CL}$ were intermediate between values detected in GC and TC while there was less BMP7 mRNA and much less activin $\beta A$ mRNA in $C L$ than in either GC or TC. The relative abundance of BMPRII and ActRIIA transcripts was greater in $\mathrm{CL}$ tissue than in either GC or TC while transcript abundance for the other five receptors examined was lower in CL than in follicular GC or TC.

Table 1 Comparison of relative ${ }^{a}$ fold-differences in mRNA transcript levels in ex vivo samples of bovine corpus luteum and follicular granulosa and theca interna tissue.

\begin{tabular}{|c|c|c|c|c|c|c|c|}
\hline \multirow[b]{2}{*}{$\begin{array}{l}\text { mRNA } \\
\text { transcript }\end{array}$} & \multirow[b]{2}{*}{$\begin{array}{c}\text { Granulosa } \\
(n=9)\end{array}$} & \multirow[b]{2}{*}{$\begin{array}{l}\text { Theca interna } \\
\qquad(n=8)\end{array}$} & \multicolumn{3}{|c|}{ Corpus luteum } & \multicolumn{2}{|c|}{ Significance (ANOVA) } \\
\hline & & & Early $(n=4)$ & $\operatorname{Mid}(n=5)$ & Late $(n=3)$ & F ratio & $P$ value \\
\hline \multicolumn{8}{|l|}{ Ligands } \\
\hline BMP2 & $6.28 \pm 1.81^{*}$ & $0.19 \pm 0.04^{\dagger}$ & $0.49 \pm 0.13^{+}$ & $0.75 \pm 0.17^{\dagger}$ & $0.93 \pm 0.31^{\dagger}$ & 5.54 & $<0.01$ \\
\hline BMP4 & $0.44 \pm 0.10^{*}$ & $1.17 \pm 0.01^{\dagger}$ & $1.12 \pm 0.15^{\dagger}$ & $0.68 \pm 0.15^{*,+}$ & $1.07 \pm 0.35^{\dagger}$ & 3.62 & $<0.02$ \\
\hline BMP6 & $0.32 \pm 0.10^{*}$ & $2.70 \pm 0.70^{+}$ & $0.34 \pm 0.06 *$ & $0.53 \pm 0.11^{*}$ & $0.75 \pm 0.15 *$ & 7.64 & $<0.001$ \\
\hline BMP7 & $0.32 \pm 0.07^{*}$ & $3.94 \pm 0.80^{\dagger}$ & $0.12 \pm 0.04 *$ & $0.14 \pm 0.08^{*}$ & $0.84 \pm 0.47^{*}$ & 14.96 & $<0.0001$ \\
\hline Activin $\beta A$ & $1.45 \pm 0.23^{*}$ & $0.33 \pm 0.07^{\dagger}$ & $0.02 \pm 0.00^{\dagger}$ & $0.02 \pm 0.01^{\dagger}$ & $0.11 \pm 0.06^{\dagger}$ & 17.79 & $<0.0001$ \\
\hline \multicolumn{8}{|l|}{ Receptors } \\
\hline BMPRIA & $1.01 \pm 0.18^{*}$ & $1.03 \pm 0.07 *$ & $0.19 \pm 0.01^{+}$ & $0.20 \pm 0.03^{+}$ & $0.13 \pm 0.02^{+}$ & 11.57 & $<0.0001$ \\
\hline BMPRIB & $1.15 \pm 0.20^{*}$ & $0.75 \pm 0.07 *$ & $0.16 \pm 0.05^{+}$ & $0.24 \pm 0.08^{\dagger}$ & $0.19 \pm 0.09^{\dagger}$ & 6.77 & $<0.001$ \\
\hline BMPRII & $0.66 \pm 0.05^{*}$ & $1.10 \pm 0.11^{*}$ & $1.45 \pm 0.34^{+}$ & $2.18 \pm 0.36^{+}$ & $1.75 \pm 0.11^{\dagger}$ & 8.96 & $<0.0001$ \\
\hline ActRIA & $0.60 \pm 0.11 *$ & $1.58 \pm 0.08 *$ & $0.47 \pm 0.04 *$ & $0.62 \pm 0.05 *$ & $0.50 \pm 0.09 *$ & 1.99 & 0.13 \\
\hline ActRIB & $2.03 \pm 0.38^{*}$ & $0.63 \pm 0.05 *$ & $0.56 \pm 0.04 *$ & $0.55 \pm 0.04 *$ & $0.55 \pm 0.10^{*}$ & 2.62 & 0.06 \\
\hline ActRIIA & $0.84 \pm 0.10^{*}$ & $1.09 \pm 0.14^{*}$ & $1.29 \pm 0.15^{*, \dagger}$ & $1.47 \pm 0.16^{\dagger}$ & $0.86 \pm 0.15^{*}$ & 2.85 & $<0.05$ \\
\hline ActRIIB & $1.28 \pm 0.15^{*}$ & $0.83 \pm 0.11^{*,+}$ & $0.43 \pm 0.04^{\dagger, \neq}$ & $0.62 \pm 0.09^{+, \neq}$ & $0.86 \pm 0.16^{*,+}$ & 4.08 & $<0.01$ \\
\hline \multicolumn{8}{|c|}{ Steroidogenesis } \\
\hline STAR & $0.39 \pm 0.12 *$ & $1.80 \pm 0.38^{*}$ & $15.4 \pm 1.82^{\dagger}$ & $29.6 \pm 4.01^{\ddagger}$ & $1.02 \pm 0.79 *$ & 47.2 & $<0.0001$ \\
\hline CYP11A1 & $0.35 \pm 0.06^{*}$ & $2.04 \pm 0.29^{\dagger}$ & $3.15 \pm 0.19^{\ddagger}$ & $4.62 \pm 0.64^{\S}$ & $0.35 \pm 0.06^{*}$ & 35.3 & $<0.0001$ \\
\hline HSD3B1 & $0.63 \pm 0.17^{*}$ & $1.60 \pm 0.21^{*}$ & $6.43 \pm 0.74^{+}$ & $9.41 \pm 1.43^{\ddagger}$ & $0.27 \pm 0.17^{*}$ & 37.4 & $<0.0001$ \\
\hline CYP17A1 & $0.04 \pm 0.01 *$ & $12.03 \pm 2.97^{+}$ & $0.15 \pm 0.08 *$ & $0.05 \pm 0.03 *$ & $0.14 \pm 0.08^{*}$ & 12.3 & $<0.0001$ \\
\hline CYP19A1 & $1.76 \pm 0.50^{*}$ & $0.23 \pm 0.02^{+}$ & $0.16 \pm 0.05^{+}$ & $0.30 \pm 0.13^{+}$ & $0.01 \pm 0.00^{+}$ & 5.45 & $<0.01$ \\
\hline
\end{tabular}

$\Delta C_{\mathrm{t}}$ values for each transcript in a given sample were re-normalized to the mean $\Delta C_{\mathrm{t}}$ value for that transcript in all tissue samples. Within rows, means without a common superscript are significantly different $(P<0.05)$. It is not possible to make 'between-row' statistical comparisons (i.e. between levels of expression of different transcripts).

aRelative levels of each transcript were determined using the $\Delta \Delta C_{\mathrm{t}}$ method with $\beta$-actin as the control 'housekeeping' gene. 


\section{Evidence for serum-induced in vitro luteinization of $G C$ and TC}

Figure 1A shows that after 6 days of culture in serumsupplemented medium, relative abundance of CYP19A1 mRNA (normalized to $\beta$-actin transcript abundance) in GC was 50-fold lower than in GC cultured in serum-free medium $(P<0.01)$. Conversely, expression of HSD3B1 was 7 -fold higher in serum-treated GC $(P<0.01)$. Relative amounts of STAR and CYP11A1 transcript were similar in serum-treated and serum-free GC cultures. Oestradiol concentration in GC-conditioned medium was threefold lower in serum-treated cultures while P4 concentration was fourfold higher. Viable cell number was $\sim 10$-fold higher in serum-treated cultures than in serum-free cultures (Fig. 1A). Treatment with an optimal dose-level of FSH $(0.33 \mathrm{ng} / \mathrm{ml})$ promoted a marked ( $\sim 20$-fold) rise in oestradiol secretion by serum-free GC cultures but had no effect on oestradiol secretion from serum-treated GC cultures (data not shown).

Figure 1B shows that the relative amount of CYP17A1 mRNA in serum-treated TC was about 1000 -fold lower than in TC cultured in serum-free medium $(P<0.0001)$. Relative amounts of STAR ( $\sim 11$-fold; $P<0.01$ ), CYP11A1 ( $~ 2$-fold; $P>0.05$ ) and HSD3B1 (5-fold; $P<0.05$ ) mRNA were also reduced in serum-treated TC but to much lesser extents than CYP17A1 mRNA. Androstenedione concentration in TC-conditioned medium was $>100$-fold lower in serumtreated cultures (reduced below assay detection limit) while P4 concentration was $\sim 3$-fold higher than in serum-free cultures. Viable cell number was $\sim 6$-fold higher in serumtreated TC cultures than in serum-free cultures.

\section{In vitro-luteinized GC and TC: effects of BMP6 and activin $A$ on progesterone secretion}

Treatment with BMP6 dose-dependently reduced forskolin-induced P4 secretion from luteinized GC $(P<0.001)$ and TC $(P<0.0001)$ without affecting viable cell number at the end of culture (Fig. 2). BMP6 did not significantly affect 'basal' P4 secretion in the absence of forskolin stimulation. As shown in Fig. 3, activin A also reduced forskolin-induced P4 secretion from both GC $(P<0.0001)$ and TC $(P<0.001)$ without affecting cell number. 'Basal' P4 secretion by GC, but not TC, was also suppressed by activin A.

\section{In vitro-luteinized GC and TC: effect of BMP6 on abundance of $m R N A$ transcripts}

Neither BMP6 nor forskolin treatment, alone or in combination, had any effect on $\beta$-actin mRNA abundance, justifying the use of this transcript as a normalization control in both luteinized GC and TC (data not shown). Treatment of GC with BMP6 decreased forskolin-induced expression of CYP11A1 by $40 \%(P<0.05)$ but had no significant effects on transcript levels for STAR and HSD3B1 either in the presence or absence of forskolin
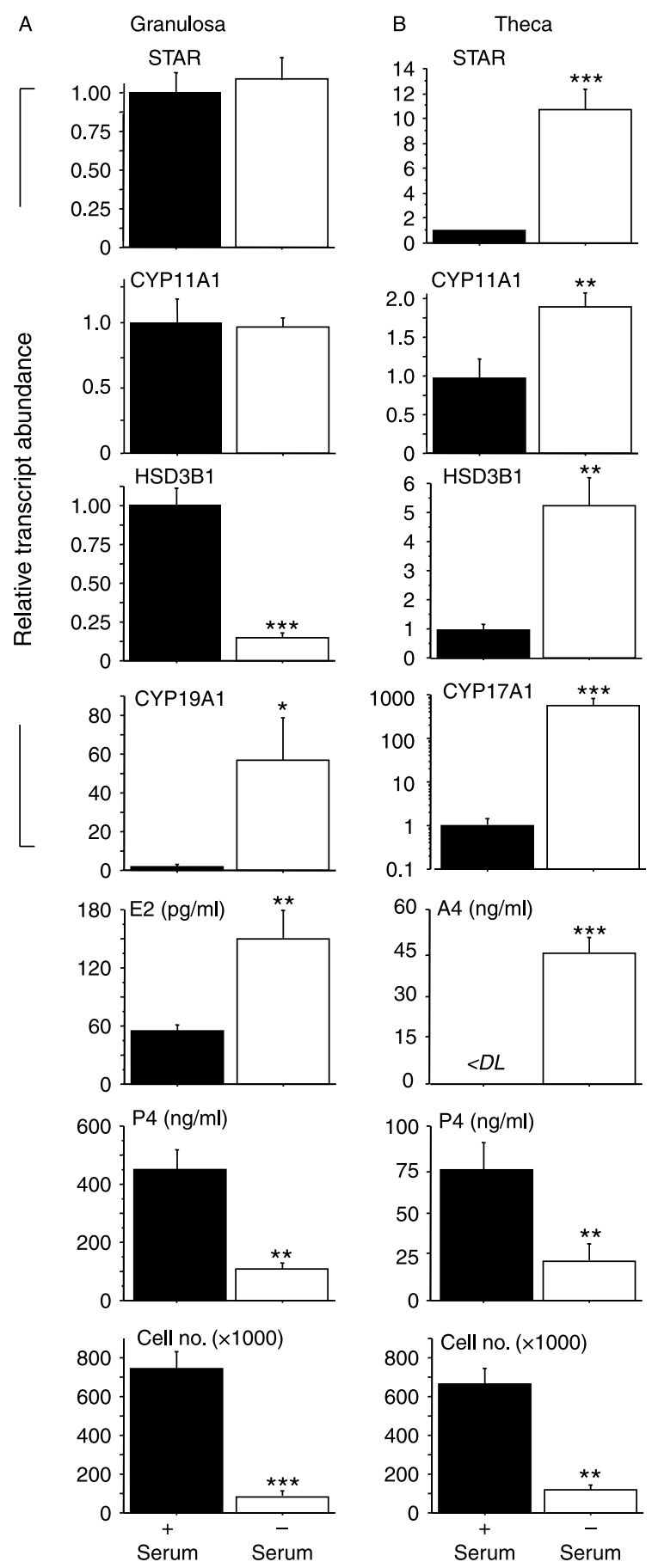

Figure 1 Comparison of STAR, CYP11A1, HSD3B1 and CYP19A1 or CYP17A1 transcript abundance (normalized to $\beta$-actin), steroid secretion and viable cell number in (A) GC and (B) TC after 6-day culture in serum-supplemented (black bars) or serum-free (white bars) medium. Steroid secretion values are for the final (96-144 h) culture period. Transcript abundance has been re-normalized to mean values in serum-treated cells. Values are means \pm s.E.M. $(n=4$ independent cultures). ${ }^{*} P<0.05,{ }^{* *} P<0.01,{ }^{* * *} P<0.001$ compared with corresponding bar. 


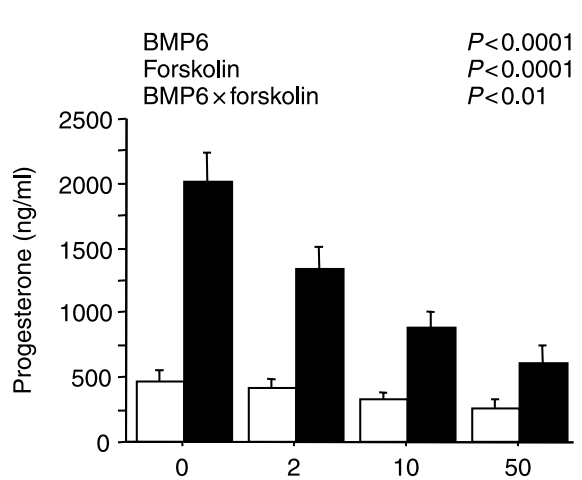

Theca
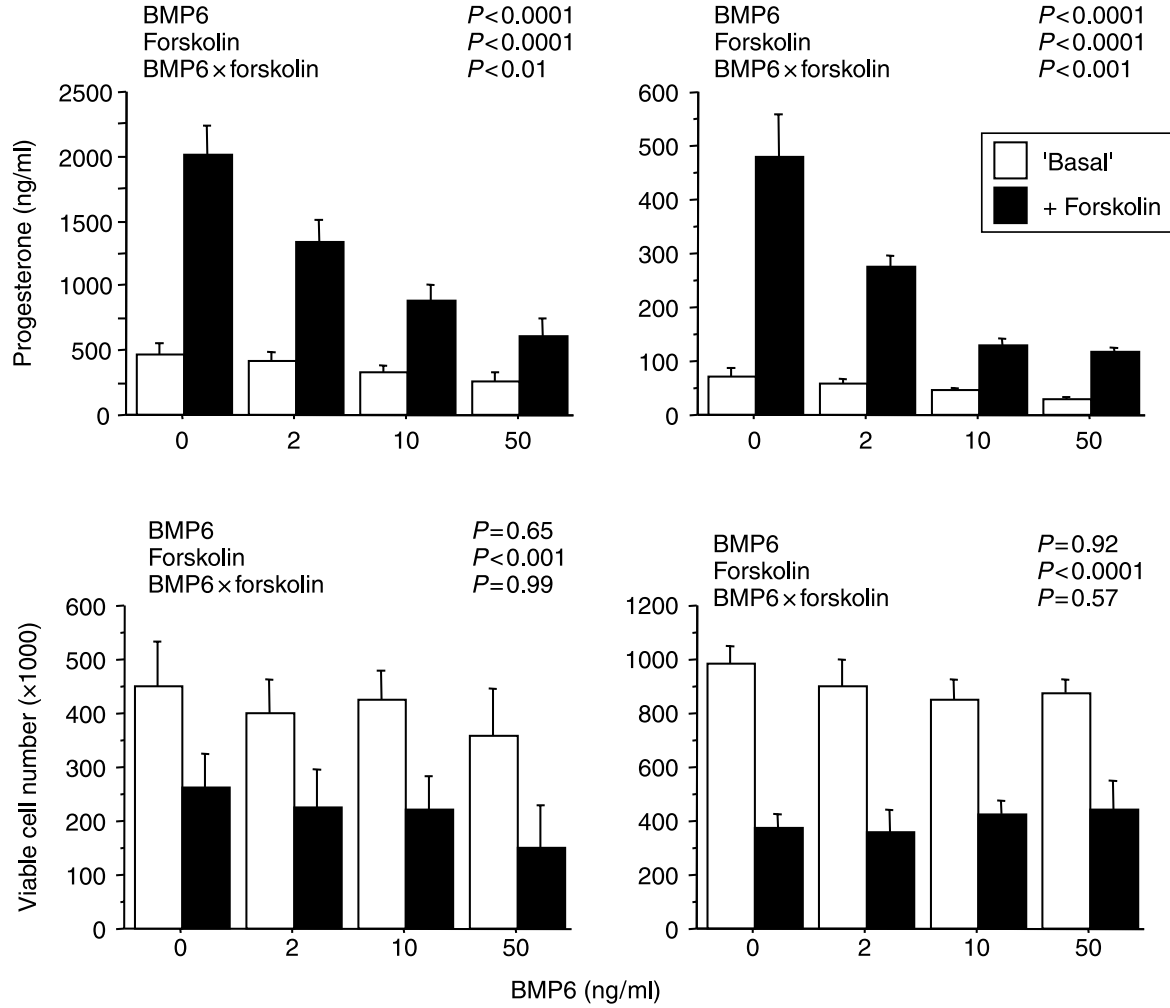

Figure 2 Effect of BMP6 on basal and forskolin-induced secretion of progesterone by luteinizing bovine (A) granulosa cells and (B) theca interna cells. The lower panel shows the viable cell number at the end of the culture period. Results presented are for the final (96-144 h) culture period. Values are \pm S.E.M. ( $n=3$ independent cultures).
(Fig. 4A). Forskolin treatment greatly ( $>100$-fold) enhanced levels of oxytocin and CYP19A1 mRNA in GC and BMP6 reduced these responses by $75 \%$ and $62 \%$ respectively $(P<0.05)$. As shown in Fig. 4B treatment of TC with BMP6 abolished forskolin-induced up-regulation of STAR mRNA $(P<0.05)$ but had no effect on CYP11A1 or HSD3B1 mRNA levels. BMP6 also increased 'basal' expression of CYP17A1 mRNA about 5 -fold $(P<0.05)$.

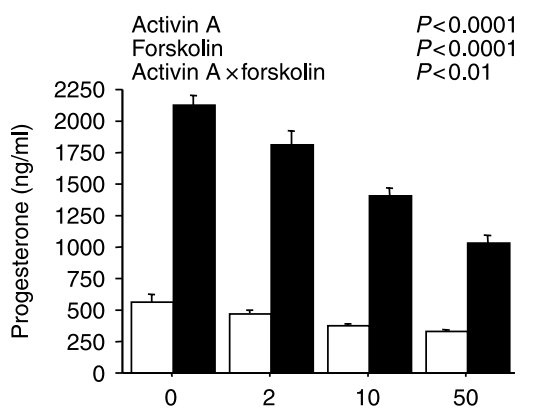

B
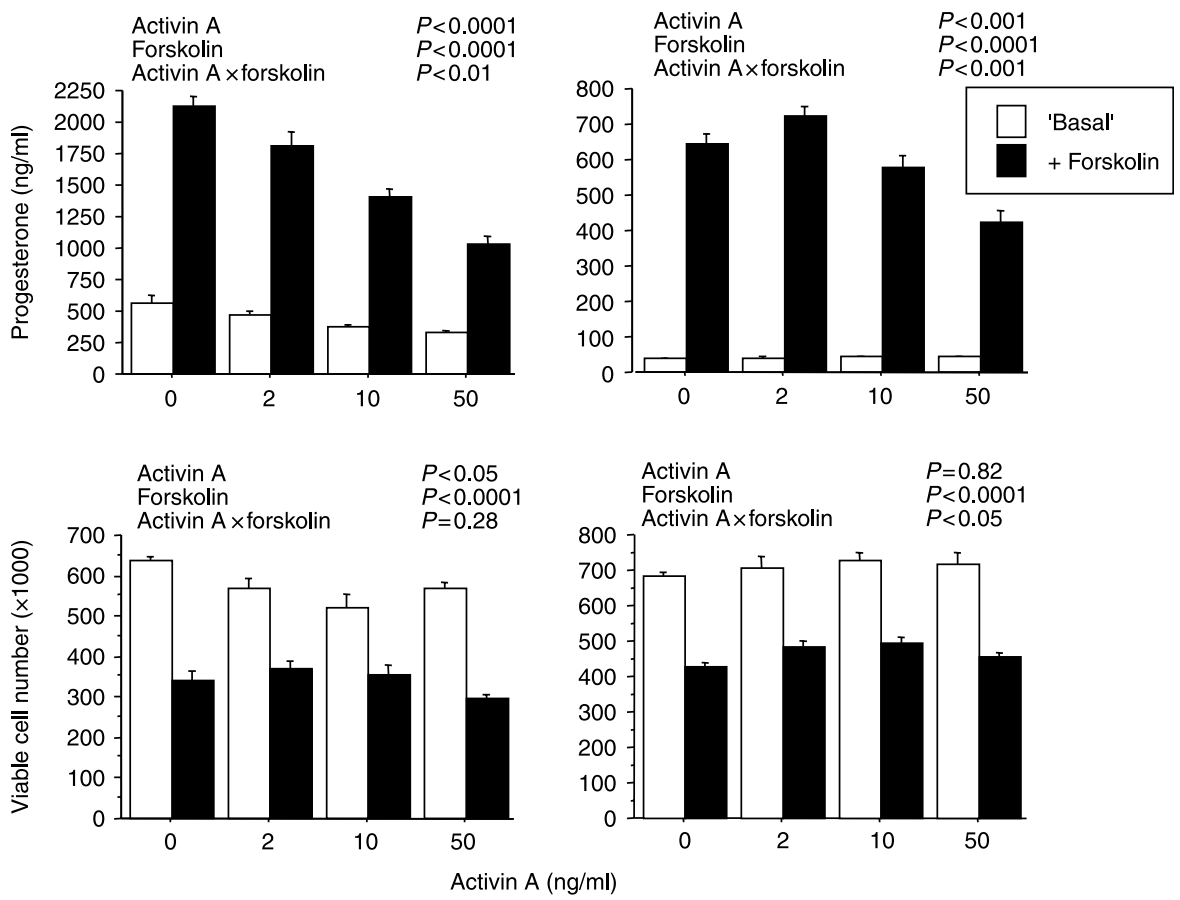

Figure 3 Effect of activin A on basal and forskolin-induced secretion of progesterone by luteinizing bovine (A) granulosa cells and (B) theca interna cells. The lower panel shows the viable cell number at the end of the culture period. Results presented are for the final (96-144 h) culture period. Values are \pm S.E.M. $(n=3$ independent cultures). 

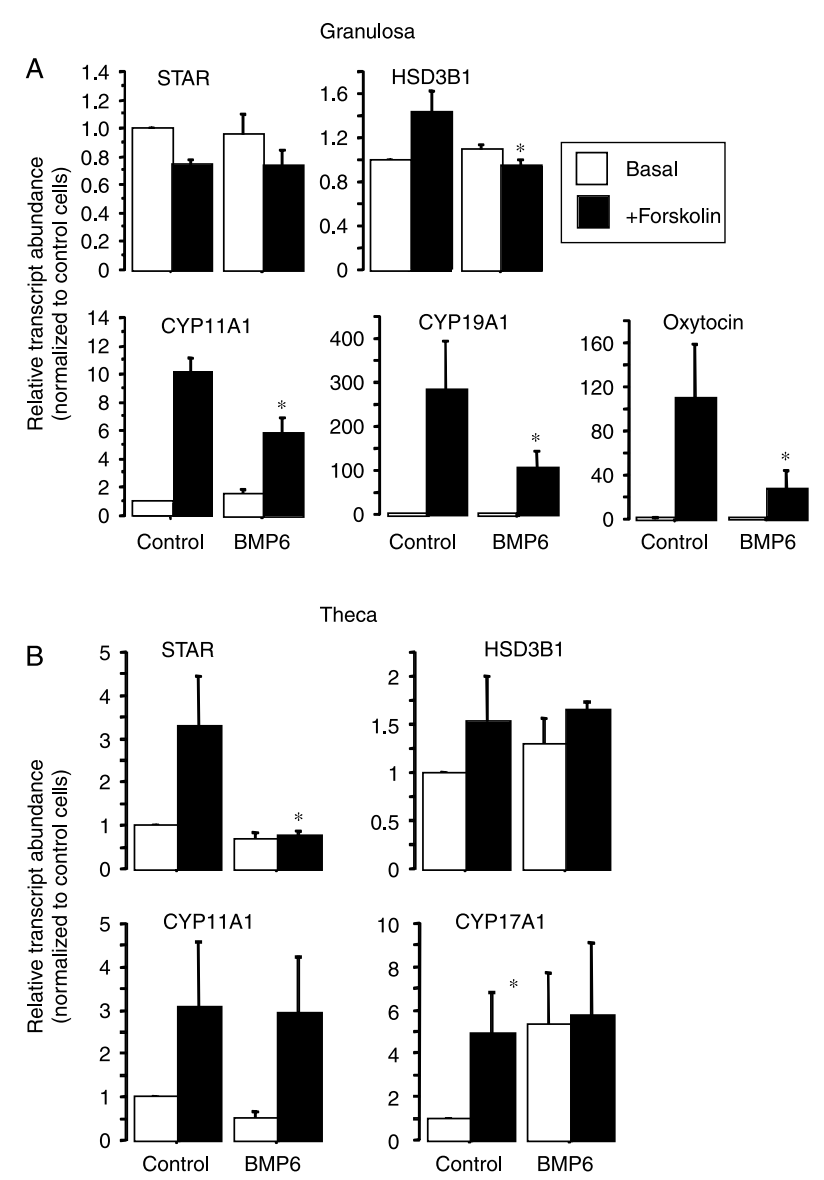

Figure 4 Effect of BMP6 $(20 \mathrm{ng} / \mathrm{ml})$ treatment, in the presence and absence of forskolin, on relative abundance of mRNA transcripts in luteinizing bovine (A) granulosa cells and (B) theca interna cells. Values are \pm S.E.M. ( $n=4$ independent cultures). ${ }^{*} P<0.05$ compared with corresponding bar in control cells without BMP6 treatment.

\section{Can follistatin inhibit effects of activin A and BMP6 on luteinizing $G C$ and $T C$ ?}

Follistatin reversed $(P<0.05)$ the suppressive effect of activin A on forskolin-induced P4 secretion from GC (Fig. 5). At the highest follistatin dose-level tested $(500 \mathrm{ng} / \mathrm{ml})$ follistatin also attenuated the activin A-induced decline in $\mathrm{P} 4$ production by TC. Follistatin alone did not affect P4 secretion by either GC or TC and did not affect viable cell number at the end of culture. As shown in Fig. 6 follistatin partially reversed $(P<0.05)$ the suppressive effect of BMP6 on P4 secretion by both cell types, but only at the highest dose-level tested (500 ng/ml).

\section{Does BMP6 affect secretion of endogenous activin A and follistatin by luteinizing $G C$ ?}

Figure 7 shows effect of BMP6 on activin A and follistatin secretion by GC in the presence and absence of forskolin. BMP6 $(P<0.05)$ decreased activin A secretion in the presence of forskolin with no effect in the absence of forskolin. However, follistatin secretion was increased significantly both in the presence $(P<0.05)$ and absence $(P<0.005)$ of forskolin resulting in a significant decline $(P<0.05)$ in activin A:follistatin mass ratio.

\section{Discussion}

This study provides several lines of evidence to support a functional involvement of BMP signalling in the follicular-luteal transition in cattle. First, ex vivo analysis of gene expression showed that mRNA transcripts for several BMPs (BMP2, -4, -6) and BMP-responsive receptors (ActRIA, ActRIIA, BMPRII) are present in bovine $\mathrm{CL}$ tissue in amounts broadly comparable with those in follicular GC and/or TC compartments. By contrast, expression of activin $\beta A$ mRNA, a major transcript in follicular GC, was extremely low in CL $(\sim 75-$ fold lower than in GC), indicating that little activin A (or inhibin-A) is synthesized by bovine $\mathrm{CL}$ and that the endogenous ligand(s) which bind to the type I and -II receptors shown to be expressed in this tissue is more likely to be $B M P(s)$. This finding of greatly reduced activin $\beta A$ expression in $C L$ agrees with previous reports of a marked fall in GC expression of inhibin/activin $\alpha$ and $\beta A$ subunits after the LH surge in cattle (Rodgers et al. 1989, Ireland \& Ireland 1994) but, to our knowledge, this is the first comparison of relative expression of BMPs and their receptors in bovine follicles and CL. In contrast to the bovine ovary, expression of inhibin/activin $\alpha$ and $\beta A$ subunits by granulosa-lutein cells is maintained in humans and primates (Fraser et al. 1993, Roberts et al. 1993). Indeed, circulating levels of inhibin-A are maximal during the luteal phase of the human menstrual cycle (Muttukrishna et al. 1994). Low levels of activin A were detectable by ELISA in bovine luteinized GC-conditioned media but, in the absence of suitable BMP immunoassays, the extent to which different BMPs are secreted by the cultured cells is unknown at this stage.

Recent studies utilizing chemically-defined, serum-free culture systems for bovine and ovine GC (Campbell et al. 1996, 2006, Gutiérrez et al. 1997, Glister et al. 2001, 2004) and TC (Glister et al. 2005, Campbell et al. 2006) have provided useful insights into the 'follicular' phenotype in which GC express CYP19A1 and are responsive to FSH in terms of upregulation of CYP19A1 expression and oestrogen production; correspondingly TC expression of CYP17A1 is maintained and the cells are responsive to $\mathrm{LH}$ in terms of upregulation of CYP17A1 expression and androgen production. In the present study, aimed at exploring the potential actions of BMPs in the follicularluteal transition and CL function in the bovine, we utilized a serum-supplemented culture model (Channing \& Ledwitz-Rigby 1975, Skinner \& Osteen 1988, Luck et al. 1990, Engelhardt et al. 1991, Wrathall \& Knight 1993) in which both GC and TC undergo phenotypic changes in vitro that, in many respects, mimic those associated with luteinization in vivo. Foetal bovine serum (FBS) was 

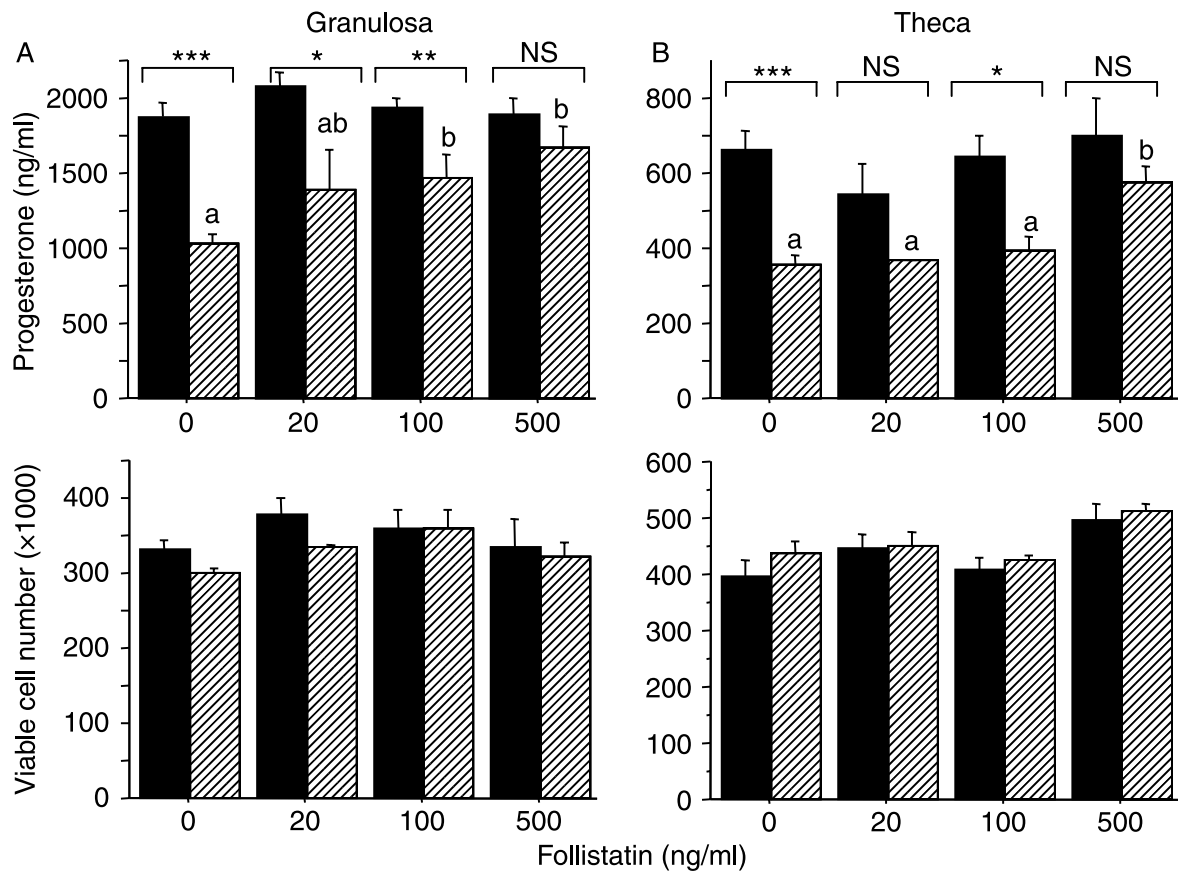

Figure 5 Effect of follistatin on activin A induced suppression of progesterone secretion by (A) granulosa cells and (B) theca interna cells in the presence of $10 \mu \mathrm{M}$ forskolin. The lower panel shows the viable cell number at the end of the culture period. Results presented are for the final (96-144 h) culture period. Values are \pm S.E.M. $(n=3$ independent cultures). ${ }^{*} P<0.05, * * P<0.01$

Vehicle $\square$ Activin A $(50 \mathrm{ng} / \mathrm{ml})$ $* * * P<0.001$ versus corresponding value.

able to induce such changes characteristic of luteinization in both cell-types as evidenced by increased $\mathrm{P} 4$ secretion and cell proliferation (GC and TC), greatly diminished 'basal' expression of CYP17A1 and androgen secretion by
TC, and reduced expression of CYP19A1 and oestrogen secretion by GC. FBS-treated GC also displayed a sevenfold increase in 'basal' HSD3B1 expression consistent with an increased production of P4. In the case of TC,
A
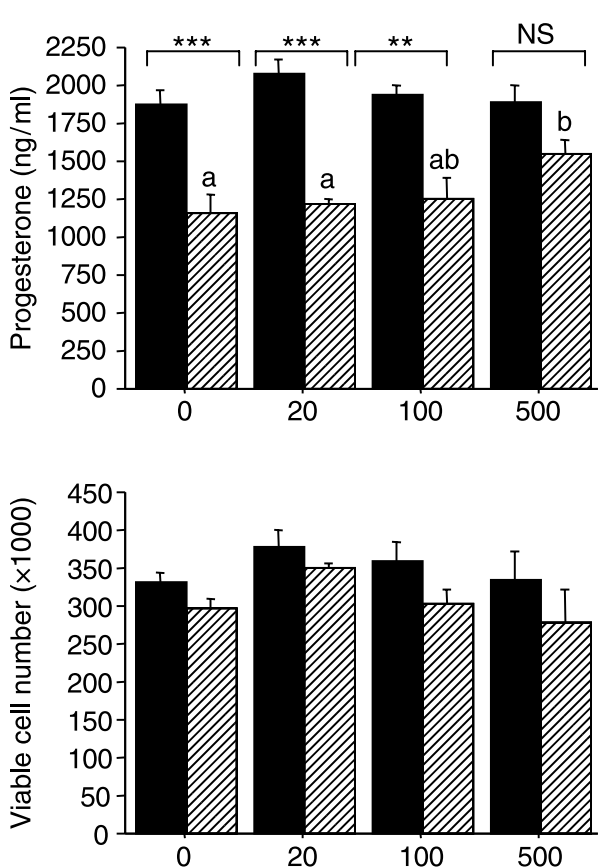

B
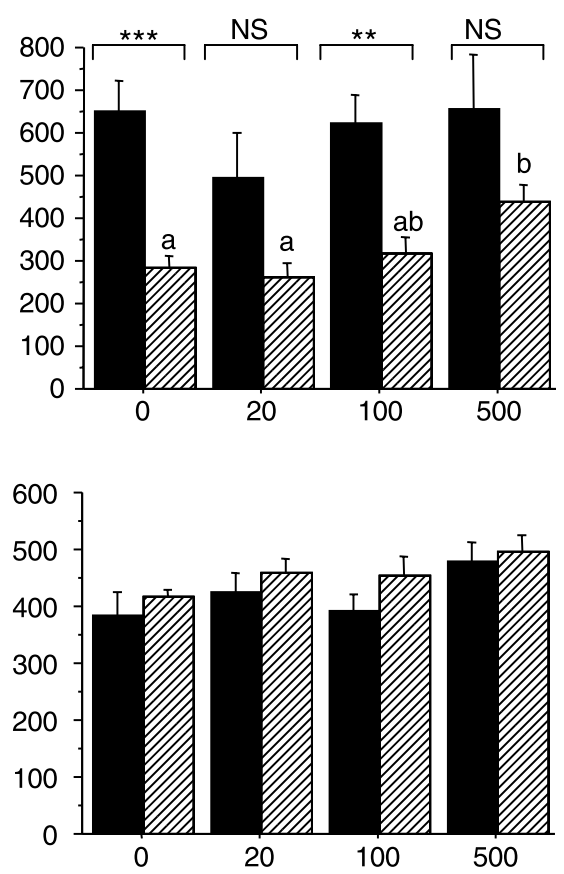

Follistatin (ng/ml)

Vehicle $\mathbb{B M P 6}(20 \mathrm{ng} / \mathrm{ml})$

Figure 6 Effect of follistatin on BMP6 induced suppression of progesterone secretion by (A) bovine granulosa cells and (B) theca interna cells in the presence of $10 \mu \mathrm{M}$ forskolin. The lower panel shows the viable cell number at the end of the culture period. Results presented are for the final (96-144 h) culture period. Values are \pm s.E.M. $(n=4$ independent cultures). ${ }^{* *} P<0.01$ $* * * P<0.001$ versus corresponding value. 

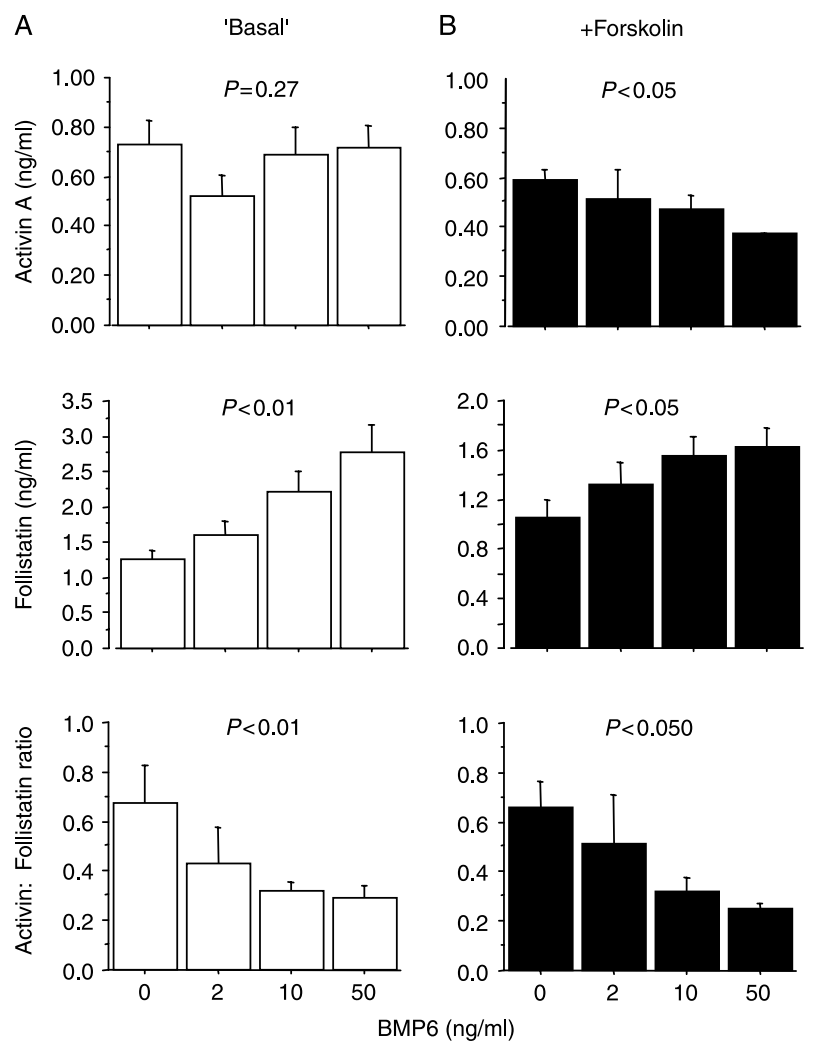

Figure 7 Effect of BMP6 on secretion of activin A and follistatin by bovine granulosa cells cultured in the $(A)$ presence and $(B)$ absence of $10 \mu \mathrm{M}$ forskolin. The lower panels show activin A:follistatin mass ratio. Values are \pm s.E.M. ( $n=4$ independent cultures). $P$ values from one-way ANOVA are shown.

however, 'basal' expression levels (normalized to $\beta$-actin) of several components of the steroidogenic pathway (STAR, CYP11A1, HSD3B1) necessary for P4 synthesis were lower in FBS-treated cultures than in serum-free cultures, albeit not to the extent observed for CYP19A1 expression which was reduced by three orders of magnitude. To our knowledge the relative contributions of granulosa-lutein cells ('large luteal cells') and thecalutein cells ('small luteal cells') to CL output of P4 in vivo has not been established and so it is difficult to ascertain the significance of this observation in relation to the validity of our in vitro luteinized TC model.

Based on viable cell number at the end of the 6-day culture period, it is clear that proliferation and/or survival of both GC and TC is much greater in the presence of FBS. Whilst intense cellular proliferation accompanies the rapid growth of ruminant $\mathrm{CL}$ tissue in vivo much of this is believed to involve endothelial cells and fibroblasts. However, both TC-derived 'small luteal cells' and, to a lesser degree, GC-derived 'large luteal cells' also proliferate, particularly in the early stages of CL formation (Jablonka-Shariff et al. 1993, Zheng et al. 1994). It is possible that FBS-stimulated proliferation of 'contaminating' endothelial cells and/or fibroblasts during the 6-day period of TC culture could account, at least in part, for the apparently lower relative expression of STAR, CYP11A1 and HSD3B1, compared with expression in serum-free TC cultures.

Of several BMP members found to be expressed in bovine $C L$ we selected BMP6 for testing in our luteinized GC and TC model. Since activin A has been used in previous studies on human/primate granulosa-lutein cells (see below), we also included activin A in many of our experiments. The observation that both BMP6 and activin $\mathrm{A}$ inhibit forskolin-induced $\mathrm{P} 4$ secretion by luteinizing TC and GC suggests a negative autocrine/ paracrine action of these, or related, TGF $\beta$ superfamily ligands on luteal steroidogenesis in cattle. Previously, activin $\mathrm{A}$ has been shown to reduce basal and hCGinduced P4 secretion by human (Rabinovici et al. 1990, Di Simone et al. 1994) and macaque (Brannian et al. 1992) granulosa-lutein cells in a follistatin-reversible manner (Cataldo et al. 1994) but, to our knowledge, effects on theca-lutein cells have not been reported previously.

Consistent with its negative effect on $\mathrm{P} 4$ secretion by luteinizing GC, BMP6 also reduced forskolin-induced upregulation of CYP11A1 and HSD3B1 mRNA expression. Likewise, forskolin-induced upregulation of CYP19A1 and oxytocin expression were reduced. Previously activin A was shown to reduce oxytocin secretion by bovine GC in vitro (Shukovski \& Findlay 1990). Although we did not measure oestradiol secretion in this experiment, the observation that luteinizing GC express low but detectable amounts of CYP19A1 mRNA and that forskolin treatment augments CYP19A1 expression is consistent with reported ability of bovine $\mathrm{CL}$ to produce small amounts of oestradiol (Okuda et al. 2001). In the case of luteinizing TC, the inhibition of forskolin-induced P4 production by BMP6 appeared to operate through a different mechanism from that in luteinizing GC; forskolin-induced upregulation of STAR mRNA was abolished but neither CYP11A1 nor HSD3B1 transcript levels were affected. In addition, BMP6 upregulated basal expression of CYP17A1, consistent with an anti-luteinization role, since thecal androgen synthesis is known to fall sharply during luteinization (Meidan et al. 1990, Mamluk et al. 1998) and androstenedione levels were undetectable in 'basal' conditioned media from these cells.

The proposed role for activin in delaying the onset of follicle atresia and/or luteinization referred to above was based on the finding that activin enhanced CYP19A1 activity and oestradiol production, while inhibiting P4 secretion by non-luteinized GC (Hutchinson et al. 1987, Shukovski et al. 1991). In a similar manner BMP4 and -7 enhanced FSH-stimulated steroidogenesis in cultured rat GC (Shimasaki et al. 1999) and BMP2 enhanced oestradiol production in cultured sheep GCs (Souza et al. 2002). Likewise, BMP2, $-4,-6$ or -7 increased basal and IGF-induced oestradiol production by non-luteinized bovine (Glister et al. 2004) and ovine 
(Campbell et al. 2006) GC while suppressing P4 production (Glister et al. 2004).

Experiments on non-luteinized human, rat and bovine TC have shown reduced $\mathrm{LH}$ - and/or forskolin-induced androgen production following treatment with activin (Hsueh et al. 1987, Hillier \& Miro 1993, Wrathall \& Knight 1995). More recently several BMPs were also shown to suppress androgen production by nonluteinized TC in a manner similar to activin A (human: Dooley et al. 2000, bovine: Glister et al. 2005; ovine: Campbell et al. 2006). In two of these reports (Dooley et al. 2000, Glister et al. 2005) decreased androgen production was associated with an increase in P4 production, evidently due to a profound reduction in CYP17A1 expression and $17 \alpha$ hydroxylase activity.

The ability of BMP6 to reduce P4 secretion by luteinized bovine GC accords with studies showing anti-P4 effects of several BMPs (including BMP6) on nonluteinized bovine GC (Glister et al. 2004). However, the negative effect of BMP6 on P4 output by luteinized TC contrasts with the positive effect of BMP4, -6 and -7 on P4 output by non-luteinized TC (Glister et al. 2005). The likely explanation for this is the divergent effect on expression of CYP17A1 that was upregulated by BMP6 in luteinized TC (present study) but downregulated by BMPs in non-luteinized TC (Glister et al. 2005). By blocking conversion to androgen, an acute loss of CYP17A1 could lead to a net increase in P4 despite a partial reduction in STAR, CYP11A1 and HSD3B1. In contrast to the positive effect of BMP6 on cell number in non-luteinized bovine GC and TC cultures (Glister et al. 2004, 2005), no effect of BMP6 on cell number was observed in this study on luteinized GC and TC. Consistent with the activin A effects on luteinized GC and TC cells similar inhibitory effects of activin have been reported on P4 secretion by cultured monkey luteal cells (Brannian et al. 1992) and on basal and hCGinduced P4 secretion from human granulosa-lutein cells (Rabinovici et al. 1990, Di Simone et al. 1994).

It is well established that follistatin, through its activinbinding ability, can oppose the effects of activin; more recent evidence indicates that follistatin can also bind to and neutralize the effects of several BMPs (see Shimasaki et al. (2004), Knight \& Glister (2006)). The present finding that follistatin antagonized the suppressive effect of activin A and, to a lesser degree, BMP6 on P4 secretion by both cell-types supports this. It should be noted, however, that addition of follistatin alone did not enhance either 'basal' or forskolin-induced P4 secretion by luteinizing GC or TC. While this seems to contradict the earlier suggestion that follistatin has a positive role in promoting follicular atresia and/or luteinization (Shukovski et al. 1991, Findlay 1993, Knight \& Glister 2003) it is possible that endogenous levels of follistatin were already sufficiently high to neutralize endogenous activin A (or related ligand?) produced by these in vitro luteinized cells. Direct measurement of immunoreactive activin A and follistatin concentrations in luteinized GC-conditioned media indicated a 50\% excess of follistatin over activin A lending some support to this explanation.

The ability of follistatin to reduce the activin Ainduced decline in $\mathrm{P} 4$ production by luteinizing bovine GC and TC concurs with findings in human granulosalutein cells (Cataldo et al. 1994) and with the ability of follistatin to block activin A-induced phosphorylation of Smad-2 in non-luteinized bovine GC (Glister et al. 2004). Taken together with the abundant expression of follistatin transcript in both luteinized GC and bovine $\mathrm{CL}$, this suggests a role of this activin-binding protein in promoting P4 production.

BMP6 increased follistatin production from luteinized GC resulting in a decreased activin A:follistatin mass ratio. This is in accordance with a previous study on nonluteinized bovine GC showing that BMPs enhanced basal and IGF-induced secretion of follistatin while inhibiting basal and IGF-induced P4 secretion (Glister et al. 2004). Previously Tuuri et al. (1994) reported that the expression of follistatin was up-regulated by hCG in human granulosa-lutein cells, known to express considerable amounts of activin $\beta \mathrm{A}$, and presumably activin protein. In future studies, it would be of interest to examine whether expression of other binding proteins (such as noggin, chordin and gremlin) is regulated by LH/ forskolin and BMP ligands in bovine granulosa-lutein and theca-lutein cells since these are likely to play a more prominent role than follistatin in modulating BMP action in these relatively activin-deficient cells. It would also be of interest to corroborate the present findings from the in vitro luteinization model used here, by evaluating the actions and interactions of BMPs, activins and their binding proteins on primary luteal cell cultures (i.e. derived from tissue in which luteinization has occurred in vivo).

In conclusion, these findings provide evidence to support inhibitory roles for BMP/activin signalling in the follicular-luteal transition in cattle. Both BMP6 and activin $\mathrm{A}$ inhibited $\mathrm{P} 4$ production by luteinizing $\mathrm{TC}$ and $\mathrm{GC}$ but $\mathrm{BMP}(\mathrm{s})$ are likely to play a more prominent role as their expression is maintained in bovine $\mathrm{CL}$ tissue whereas expression of activin $\beta A$ subunit is greatly diminished relative to that in follicular GC.

\section{Materials and Methods}

All media and reagents were purchased from Sigma UK Ltd or Fisher Scientific Ltd (Loughborough, Leicestershire, UK) unless stated otherwise.

\section{Ovaries and isolation of GC and TC}

Ovaries from cattle slaughtered at random stages of the oestrous cycle were collected from an abattoir and transported to the laboratory in medium-199 supplemented with $1 \%(\mathrm{v} / \mathrm{v})$ 
antibiotic antimycotic solution. Samples of CL tissue (early, mid- and late-luteal phase based on criteria of Ireland et al. 1980) were removed and snap frozen for subsequent RNA isolation. Follicles, 4-6 mm in diameter, were dissected out, hemisected and GC and theca interna layers were recovered as described previously (Glister et al. 2005). For ex vivo analysis of mRNA transcripts, individual samples of granulosa and theca interna were snap frozen for subsequent RNA purification. For cell culture experiments, GC and theca interna layers pooled from $\sim 50$ follicles per culture were further processed as described by Glister et al. $(2001,2005)$ to obtain individual cell suspensions.

\section{Cell culture}

Culture medium used was McCoy's 5A modified medium supplemented with $1 \%(\mathrm{v} / \mathrm{v})$ antibiotic-antimycotic solution, $10 \mathrm{ng} / \mathrm{ml}$ insulin (bovine pancreas), $2 \mathrm{mM}$ L-glutamine, $10 \mathrm{mM}$ HEPES, $5 \mu \mathrm{g} / \mathrm{ml}$ apo-transferrin, $5 \mathrm{ng} / \mathrm{ml}$ sodium selenite, $0.1 \%$ $(\mathrm{w} / \mathrm{v}) \mathrm{BSA}$ and $5 \%(\mathrm{v} / \mathrm{v})$ FBS. Culture medium used for GC was also supplemented with $10^{-7} \mathrm{M}$ androstenedione. GC and TC were routinely seeded at a density of $10^{4}$ viable cells/50 $\mu \mathrm{l}$ culture medium, into 96-well tissue culture plates (Nunclon, Life Technologies Ltd) containing $200 \mu \mathrm{l} /$ well pre-equilibrated culture medium. Culture plates were incubated in a watersaturated atmosphere of $5 \% \mathrm{CO}_{2}$ and $95 \%$ air at $38.5{ }^{\circ} \mathrm{C}$ for a period of six days. Cell-conditioned medium was removed every $48 \mathrm{~h}$ and wells replenished with fresh medium containing treatments (see below). Conditioned media was stored at $-20^{\circ} \mathrm{C}$ for hormone immunoassays. At the end of the $144 \mathrm{~h}$ culture period viable cell number was determined using neutral red assay (Campbell et al. 1996, Glister et al. 2001). To provide a comparison between 'luteinized' (serum-treated) and 'non-luteinized' (serum-free) phenotypes, in several experiments GC and TC were split into two batches, one of which was cultured as described above, while the other was cultured in the same medium without FBS.

\section{RNA isolation from cultured cells}

In culture experiments in which total RNA was to be extracted for PCR analysis, cells were seeded into 24-well plates $\left(10^{5}\right.$ cell $\left./ \mathrm{ml}\right)$ with three replicate wells per treatment. At the end of culture cell lysates were prepared using Tri-reagent and pooled lysates from replicate wells were stored at $-80^{\circ} \mathrm{C}$ until total RNA isolation.

\section{Preparation and addition of treatments}

Forskolin (10 mM stock solution) was prepared in DMSO and further diluted in sterile culture medium (without serum and androstenedione) to a final concentration of $10 \mu \mathrm{M}$. Control wells received an appropriately matched volume of DMSO. Other treatments included recombinant human (rh) BMP6 $(0,2,10$ and $50 \mathrm{ng} / \mathrm{ml}$; R\&D Systems, Abingdon, Oxfordshire, UK), rh activin $A(0,2,10$ and $50 \mathrm{ng} / \mathrm{ml}$; R\&D Systems), and rh follistatin-288 (0, 20, 100 and $500 \mathrm{ng} / \mathrm{ml}$; National Hormone and Pituitary Program, Torrance, CA, USA). Follistatin was tested in the presence and absence of $50 \mathrm{ng} / \mathrm{ml}$ activin $A$ and
$20 \mathrm{ng} / \mathrm{ml}$ BMP6. All treatments, except forskolin, were sterilized by passing through $0.2-\mu \mathrm{m}$ filters before further dilution in sterile culture medium. Each treatment was added at $25 \mu \mathrm{l}$ per culture well and an equal volume of culture medium alone was added to the control wells.

\section{Hormone assays}

Concentrations of P4 in luteinized GC- and TC-conditioned media were determined by competitive ELISA (Sauer et al. 1986, Bleach et al. 2001). The detection limit was 20 pg/ml and intra- and inter-assay coefficients of variation (CV) were $8 \%$ and $10 \%$ respectively. Concentrations of oestradiol- $17 \beta$ and androstenedione in selected cell-conditioned media samples were determined by direct RIA as described previously (Glister et al. 2001, 2005). Detection limits were 2 and $50 \mathrm{pg} / \mathrm{ml}$ respectively and intra-and inter-assay $\mathrm{CV}$ were less than $10 \%$. Activin A concentrations in selected GC-conditioned media samples were measured using the two-site ELISA (Knight et al. 1996). The detection limit of the assay was $4 \mathrm{pg} / \mathrm{ml}$ and intraand inter-plate CV were less than $10 \%$. Follistatin concentrations in selected GC conditioned media samples were determined using two-site ELISA (Tannetta et al. 1998). The detection limit of the assay was $60 \mathrm{pg} / \mathrm{ml}$ and intra- and interplate CV were less than $11 \%$.

\section{Purification of RNA, CDNA synthesis and real-time PCR}

Total RNA was isolated from cultured cells and tissue samples using a standard acid guanidium thiocyanate-phenol-chloroform extraction method. Briefly, cell monolayers were directly lysed in $0.5 \mathrm{ml} /$ well Tri Reagent (Sigma UK Ltd) while frozen tissue samples were homogenized (Ultra-Turrax T8;) for $15-20 \mathrm{~s}$ in 20 volumes of Tri-Reagent. After aqueous phase separation, RNA was precipitated in isopropanol, washed in $75 \%(\mathrm{v} / \mathrm{v})$ ethanol and the RNA pellet was re-suspended in $50 \mu \mathrm{l}$ nuclease-free water. Potential genomic DNA contamination was removed with an RNase-free DNase kit (RQ1; Promega UK Ltd). The Tri Reagent extraction process was repeated and the final RNA pellet re-suspended in $20 \mu \mathrm{l}$ nuclease-free water; RNA quantity and quality were evaluated by spectrophotometry at 260/280 nm. First strand cDNA was synthesized from $1 \mu \mathrm{g}$ RNA template using the Reverse-iT RT kit (used according to manufacturers protocol; Abgene, Epsom, Surrey, UK) in a $20 \mu \mathrm{l}$ reaction primed with random hexamers.

Primers were designed to amplify target sequences based on criteria set by the ABI PRISM primer express software (version 1.5). Primer sequences and Entrez accession numbers are shown in Table 2. In primer validation experiments dissociation curve analysis and agarose gel electrophoresis were used to verify that each selected primer pair generated a single amplicon of the predicted size. cDNA template log-dilution curves were used to demonstrate satisfactory PCR efficiency $(>85 \%)$ and linearity. PCR assays were carried out in a volume of $25 \mu \mathrm{l}$, comprising $10 \mu \mathrm{l}$ cDNA template (equivalent to $20 \mathrm{ng}$ reversetranscribed RNA), $1 \mu$ l each forward and reverse primers (final concentration $0.4 \mu \mathrm{M}$ ) and $12 \mu$ Q QuantiTect SYBR Green QPCR $2 \times$ Master Mix (Qiagen). Samples were processed for 40 cycles on an ABI PRISM 7700 Sequence Detection System (Perkin- 


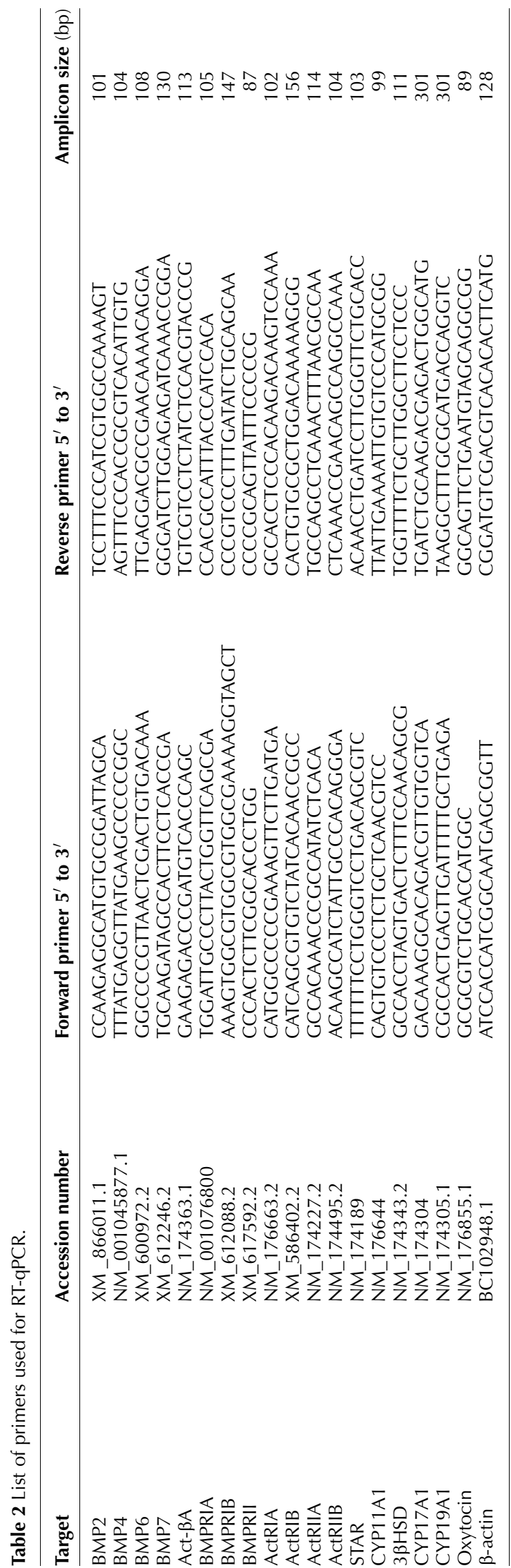

Elmer-Applied Biosystems, Warrington, UK) with the following thermal cycling conditions: 2 min at $50{ }^{\circ} \mathrm{C}, 15 \mathrm{~min}$ at $95^{\circ} \mathrm{C}, 15 \mathrm{~s}$ at $95{ }^{\circ} \mathrm{C}$ and $1 \mathrm{~min}$ at $60^{\circ} \mathrm{C}$.

The $\Delta \Delta C_{\mathrm{t}}$ method was used for semi-quantitative comparison of the abundance of each mRNA transcript. $C_{t}$ values for each transcript in a given sample were first normalized to $\beta$-actin $C_{\mathrm{t}}$ value (which was uniform across experimental all groups: ANOVA $P>0.1$ ). For cell culture experiments the resultant $\Delta C_{\mathrm{t}}$ values for each treatment were then normalized to the $\Delta C_{\mathrm{t}}$ value of the respective vehicle-treated control group. For ex vivo tissue samples (GC, TC, CL) $\Delta C_{\mathrm{t}}$ values for each transcript in a given sample were normalized to the mean $\Delta C_{\mathrm{t}}$ value for that transcript in all tissue samples. For graphical presentation $\Delta \Delta C_{\mathrm{t}}$ values were finally converted to folddifferences using the formula: fold-difference $=2^{\left(-\Delta \Delta C_{\mathrm{t}}\right)}$.

\section{Statistical analysis}

To reduce heterogeneity of variance, hormone data were logtransformed prior to statistical analysis. QPCR data were analysed as $\Delta \Delta C_{\mathrm{t}}$ values before conversion to fold-difference values. Combined results from three or four independent culture experiments were analysed using ANOVA and provided a significant $F$ ratio was obtained, post hoc pairwise comparisons were made using Fisher's protected least significant difference test. Unless otherwise stated, results are presented as arithmetic means \pm s.E.M.

\section{Declaration of interest}

The authors declare that there is no conflict of interest that would prejudice the impartiality of this scientific work.

\section{Funding}

This work was supported by the Biotechnology and Biological Sciences Research Council (grant BBS/B/10439 to P G K). A R K was supported by a postgraduate scholarship awarded by the Ministry of Science \& Technology of the Government of Pakistan.

\section{References}

Bleach EC, Glencross RG, Feist SA, Groome NP \& Knight PG 2001 Plasma inhibin-A in heifers: relationship with follicular waves, gonadotrophins and steroids during the oestrous cycle and after treatment with bovine follicular fluid. Biology of Reproduction 64 743-752.

Brannian J, Woodruff T, Mather J \& Stouffer RL 1992 Activin-A inhibits progesterone production by macaque luteal cells in culture. Journal of Clinical Endocrinology and Metabolism 75 756-761.

Campbell BK, Scaramuzzi RJ \& Webb R 1996 Induction and maintenance of oestradiol and immunoreactive inhibin production with FSH by ovine granulosa cells cultured in serum-free media. Journal of Reproduction and Fertility 106 7-16.

Campbell BK, Souza CJ, Skinner AJ, Webb R \& Baird DT 2006 Enhanced response of granulosa and theca cells from sheep carriers of the FecB mutation in vitro to gonadotropins and bone morphogenic protein-2, -4 , and -6. Endocrinology 147 1608-1620. 
Cataldo NA, Rabinovici J, Fujimoto VY \& Jaffe RB 1994 Follistatin antagonizes the effects of activin-A on steroidogenesis in human luteinizing granulosa cells. Journal of Clinical Endocrinology and Metabolism 79 272-277.

Channing CP \& Ledwitz-Rigby F 1975 Methods for assessing hormonemediated differentiation of ovarian cells in culture and in short-term incubations. Methods in Enzymology 39 183-230.

Couet J, Martel C, Dupont E, Luu-The V, Sirard M, Zhao H, Pelletier G \& Labrie F 1990 Changes in $3 \beta$-hydroxysteroid dehydrogenase $/ \Delta_{5}-\Delta_{4}$ isomerase messenger ribonucleic acid, activity and protein levels during the estrous cycle in the bovine ovary. Endocrinology 127 2141-2148.

Dooley CA, Attia GR, Rainey WE, Moore DR \& Carr BR 2000 Bone morphogenetic protein inhibits ovarian androgen production. Journal of Clinical Endocrinology and Metabolism 85 3331-3337.

Elvin JA, Yan C \& Matzuk MM 2000 Oocyte expressed TGF $\beta$ superfamily members in female fertility. Molecular and Cellular Endocrinology 159 $1-5$.

Engelhardt H, Gore-Langton RE \& Armstrong DT 1991 Luteinization of porcine thecal cells in vitro. Molecular and Cellular Endocrinology 75 237-245.

Findlay JK 1993 An update on the roles of inhibin, activin, and follistatin as local regulators of folliculogenesis. Biology of Reproduction 48 15-23.

Fraser HM, Lunn SF, Cowen GM \& Saunders PT 1993 Localization of inhibin/activin subunit mRNAs during the luteal phase in the primate ovary. Journal of Molecular Endocrinology 10 245-257.

Glister C, Tannetta DS, Groome NP \& Knight PG 2001 Interactions between follicle-stimulating hormone and growth factors in modulating secretion of steroids and inhibin-related peptides by non-luteinized bovine granulosa cells. Biology of Reproduction 65 1020-1028.

Glister C, Kemp CF \& Knight PG 2004 Bone morphogenetic protein (BMP) ligands and receptors in bovine ovarian follicle cells: actions of BMP-4, -6 , and -7 on granulosa cells and differential modulation of Smad- 1 phosphorylation by follistatin. Reproduction 127 239-254.

Glister C, Richards SL \& Knight PG 2005 Bone morphogenetic proteins (BMP) $-4,-6$, and -7 potently suppress basal and luteinizing hormoneinduced androgen production by bovine theca interna cells in primary culture: could ovarian hyperandrogenic dysfunction be caused by a defect in thecal BMP signaling? Endocrinology 146 1883-1892.

Gutiérrez CG, Campbell BK \& Webb R 1997 Development of a long-term bovine granulosa cell culture system: induction and maintenance of estradiol production, response to follicle-stimulating hormone, and morphological characteristics. Biology of Reproduction 56 608-616.

Hillier SG \& Miro F 1993 Inhibin, activin and follistatin. Potential roles in ovarian physiology. Annals of the New York Academy of Sciences 687 29-38.

Hsueh AJ, Dahl KD, Vaughan J, Tucker E, Rivier J, Bardin CW \& Vale W 1987 Heterodimers and homodimers of inhibin subunits have different paracrine action in the modulation of luteinizing hormone-stimulated androgen biosynthesis. PNAS 84 5082-5086.

Hutchinson LA, Findlay LA, de Vos FL \& Robertson DM 1987 Effects of bovine inhibin, transforming growth factor-beta and bovine activin-A on granulosa cell differentiation. Biochemical and Biophysical Research Communications 146 1405-1412.

Ireland JL \& Ireland JJ 1994 Changes in expression of inhibin/activin alpha, beta $\mathrm{A}$ and beta $\mathrm{B}$ subunit messenger ribonucleic acids following increases in size and during different stages of differentiation or atresia of non-ovulatory follicles in cows. Biology of Reproduction 50 492-501.

Ireland JJ, Murphee RL \& Coulson PB 1980 Accuracy of predicting stages of bovine estrous cycle by gross appearance of the corpus luteum. Journal of Dairy Science 63 155-160.

Jablonka-Shariff A, Grazul-Bilska AT, Redmer DA \& Reynolds LP 1993 Growth and cellular proliferation of ovine corpora lutea throughout the estrous cycle. Endocrinology 133 1871-1879.

Juengel JL \& McNatty KP 2005 The role of proteins of the transforming growth factor-beta superfamily in the intraovarian regulation of follicular development. Human Reproduction Update 11 143-160.

Knight PG \& Glister C 2003 Local roles of TGF- $\beta$ superfamily members in the control of ovarian follicle development: review. Animal Reproduction Science 78 165-183.

Knight PG \& Glister C 2006 TGF-beta superfamily members and ovarian follicle development. Reproduction 132 191-206.
Knight PG, Muttukrishna S \& Groome NP 1996 Development and application of a two-site enzyme immunoassay for the determination of 'total' activin-A concentrations in serum and follicular fluid. Journal of Endocrinology 148 267-279.

Lee WS, Otsuka F, Moore RK \& Shimasaki S 2001 Effect of bone morphogenetic protein-7 on folliculogenesis and ovulation in the rat. Biology of Reproduction 65 994-999.

Luck MR, Rodgers RJ \& Findlay JK 1990 Secretion and gene expression of inhibin, oxytocin and steroid hormones during the in vitro differentiation of bovine granulosa cells. Reproduction, Fertility, and Development $\mathbf{2}$ $11-25$.

Mamluk R, Wolfenson D \& Meidan R 1998 LH receptor mRNA and cytochrome P450 side-chain cleavage expression in bovine theca and granulosa cells luteinized by $\mathrm{LH}$ or forskolin. Domestic Animal Endocrinology 15 103-114.

Martin TL, Fogwell RL \& Ireland JJ 1991 Concentrations of inhibins and steroids in follicular fluid during development of dominant follicles in heifers. Biology of Reproduction 44 693-700.

Massague J 1996 TGF beta signaling: receptors, transducers, and mad proteins. Cell 85 947-950.

Massague J \& Chen YG 2000 Controlling TGF-beta signaling. Genes and Development 14 627-644.

Meidan R, Girsh E, Blum O \& Aberdam E 1990 In vitro differentiation of bovine theca and granulosa cells into small and large luteal-like cells: morphological and functional characteristics. Biology of Reproduction 43 913-921.

Miyazawa K, Shinosaki M, Hara T, Furuya T \& Miyazono K 2002 Two major Smad pathways in TGF- beta superfamily signaling. Genes to Cells 7 1191-1204.

Miyazono K, ten Dijke P \& Heldin CH 2000 TGF-beta signaling by Smad proteins. Advances in Immunology 75 115-157.

Muttukrishna S, Fowler PA, Groome NP, Mitchell GG, Robertson WR \& Knight PG 1994 Serum concentrations of dimeric inhibin during the spontaneous human menstrual cycle and after treatment with exogenous gonadotrophin. Human Reproduction 9 1634-1642.

Okuda K, Uenoyama Y, Berisha B, Lange IG, Taniguchi H, Kobayashi S, Kobayashi S, Miyamoto A \& Schams D 2001 Estradiol-17 $\beta$ is produced in bovine corpus luteum. Biology of Reproduction 65 1634-1639.

Rabinovici J, Spencer S \& Jaffe R 1990 Recombinant human activin-A promotes proliferation of human luteinized preovulatory granulosa cells in vitro. Journal of Clinical Endocrinology and Metabolism 71 1396-1398.

Roberts VJ, Barth S, el-Roeiy A \& Yen S 1993 Expression of inhibin/activin subunits and follistatin messenger ribonucleic acids and proteins in ovarian follicles and the corpus luteum during the human menstrual cycle. Journal of Clinical Endocrinology and Metabolism 77 1402-1410.

Rodgers RJ, Waterman MR \& Simpson ER 1987 Levels of messenger ribonucleic acid encoding cholesterol side-chain cleavage cytochrome P-450, 17 $\alpha$-hydroxylase cytochrome P-450, adrenodoxin, and low density lipoprotein receptor in bovine follicles and corpora lutea throughout the ovarian cycle. Molecular Endocrinology 1 275-279.

Rodgers RJ, Stuchbery SJ \& Findlay JK 1989 Inhibin mRNAs in ovine and bovine ovarian follicles and corpora lutea throughout the estrous cycle and gestation. Molecular and Cellular Endocrinology 62 95-101.

Sauer MJ, Foulkes JA, Worsfold A \& Morris BA 1986 Use of progesterone 11 -glucuronide-alkaline phosphatase conjugate in a sensitive microtitreplate enzymeimmunoassay of progesterone in milk and its application to pregnancy testing in dairy cattle. Journal of Reproduction and Fertility $76375-391$.

Schams D 1987 Luteal peptides and intercellular communication. Journal of Reproduction and Fertility 34 87-99.

Shimasaki S, Zachow RJ, Li D, Kim H, Lemura S, Ueno N, Sampath K, Chang RJ \& Erickson GF 1999 A functional bone morphogenetic protein system in the ovary. PNAS 96 7282-7287.

Shimasaki S, Moore RK, Otsuka F \& Erickson GF 2004 The bone morphogenetic protein system in mammalian reproduction. Endocrine Reviews 25 72-101.

Shukovski L \& Findlay JK 1990 Activin-A inhibits oxytocin and progesterone production by preovulatory bovine granulosa cells in vitro. Endocrinology 126 222-224. 
Shukovski L, Findlay JK \& Robertson DM 1991 The effect of folliclestimulating hormone-suppressing protein or follistatin on luteinizing bovine granulosa cells in vitro and its antagonistic effect on the action of activin. Endocrinology 126 3395-3402.

Di Simone ND, Ronsisvalle E, Lanzone A, Caruso A, Petraglia F \& Mancuso S 1994 Effect of activin-A on progesterone synthesis in human luteal cells. Fertility and Sterility 62 1157-1161.

Skinner MK \& Osteen KG 1988 Developmental and hormonal regulation of bovine granulosa cell function in the preovulatory follicle. Endocrinology 123 1668-1675.

Souza CJ, Campbell BK, McNeilly AS \& Baird DT 2002 Effect of bone morphogenetic protein 2 (BMP2) on oestradiol and inhibin A production by sheep granulosa cells, and localization of BMP receptors in the ovary by immunohistochemistry. Reproduction 123 363-369.

Stocco DM 2000 The role of the StAR protein in steroidogenesis: challenges for the future. Journal of Endocrinology 164 247-253.

Tannetta DS, Feist SA, Bleach ECL, Groome NP, Evans LW \& Knight PG 1998 Effects of active immunization of sheep against an amino terminal peptide of the inhibin $\alpha \mathrm{C}$ subunit on intrafollicular levels of activin A, inhibin A and follistatin. Journal of Endocrinology 157 157-168.
Tuuri T, Eramaa M, Hilden K \& Ritvos O 1994 Activin-binding protein, follistatin messenger ribonucleic acid and secreted protein levels are induced by chorionic gonadotropin in cultured human granulosa-luteal cells. Endocrinology 135 2196-2203.

Wrathall JHM \& Knight PG 1993 Production of immunoreactive inhibin by bovine granulosa cells in serum-free culture: effects of exogenous steroids and FSH. Domestic Animal Endocrinology 10 289-304.

Wrathall JHM \& Knight PG 1995 Effects of inhibin-related peptides and oestradiol on androstenedione and progesterone secretion by bovine theca cells in vitro. Journal of Endocrinology 145 491-500.

Zheng J, Fricke PM, Reynolds LP \& Redmer DA 1994 Evaluation of growth, cell proliferation, and cell death in bovine corpora lutea throughout the estrous cycle. Biology of Reproduction 51 623-632.

Received 9 May 2008

First decision 6 June 2008

Revised manuscript received 24 September 2008

Accepted 17 October 2008 